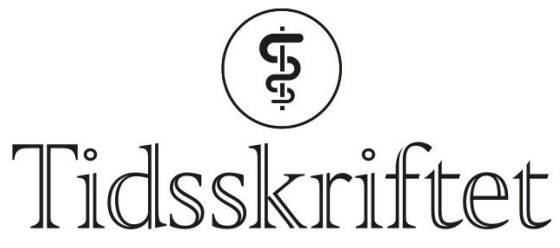

DEN NORSKE LEGEFORENING

\title{
Ufarlige bakterier beskytter mot farlige
}

FRA ANDRE TIDSSKRIFTER

HAAKON B. BENESTAD

Universitetet i Oslo

Ikke-patogene, normalt forekommende bakterier på huden produserer spesifikke peptider mot andre bakterier. Disse peptidene kan beskytte mot farlige bakterier.

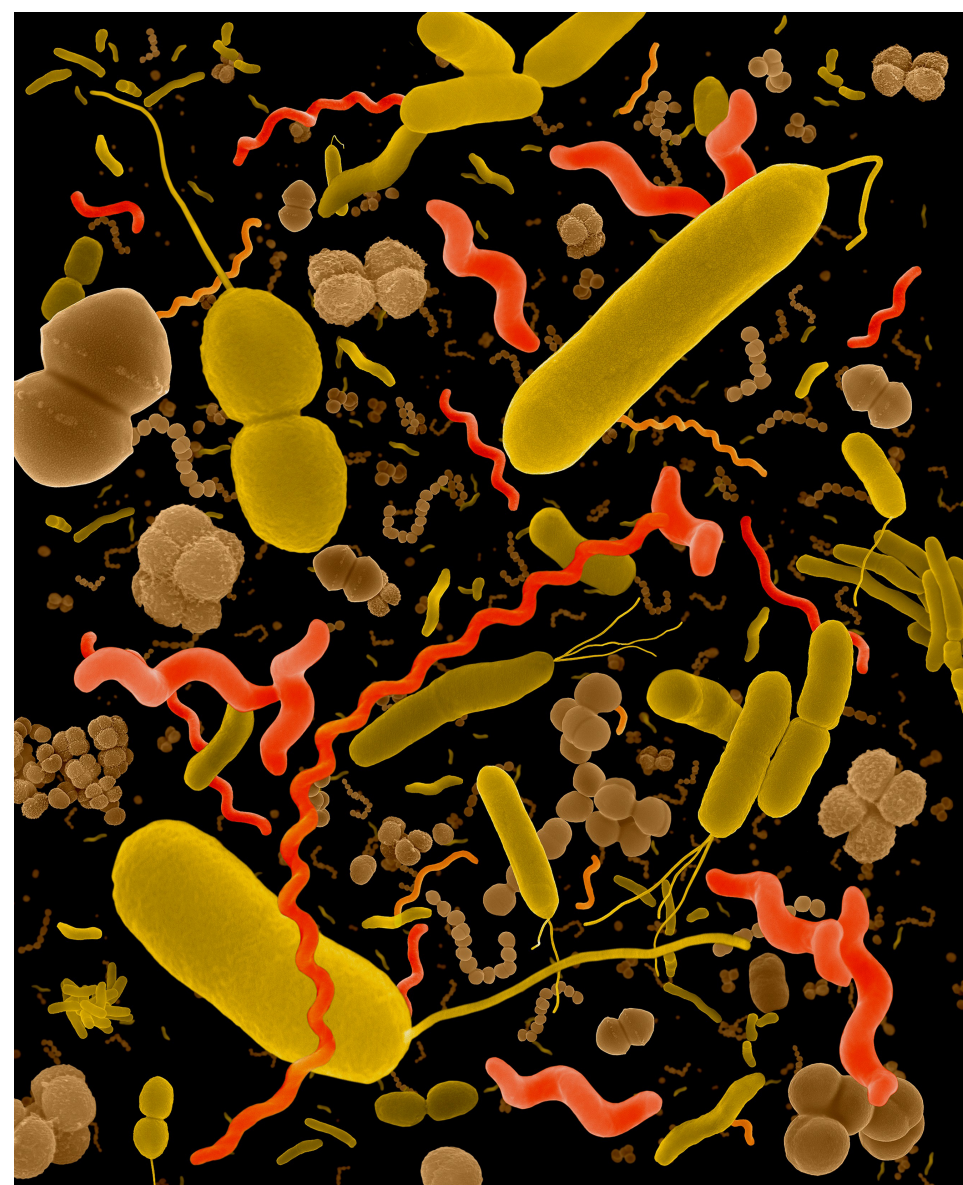

Fotosammensetning av vanlige bakterietyper, først og fremst hudbakterier, sett ved farget sveipeelektronmikroskop (scanning electron micrograph, SEM). Her ses de stavformede bakteriene Escherichia coli, Propionibacterium acnes, Corynebacterium diptheriae, og kokkene Staphylococcus aureus, Staphylococcus epidermidis, Enterococcus faecium, Micrococcus luteus. Foto: Science Photo Library 
Gule stafylokokker er en del av hudens normalflora og er særlig vanlig hos pasienter med atopisk eksem. Bakterien kan forverre eksemet og bli resistent mot antibiotika. En ny studie viser at ikke-patogene, koagulasenegative stafylokokker er vanlig på frisk hud, men ikke hos pasienter med atopisk eksem (1). I studien ble storskalasøk etter antimikrobielle peptider (AMP) utført hos de ufarlige stafylokokkene, og noen av disse produserte tidligere ukjente peptider som kan drepe gule stafylokokker. Bakterier på huden deltar altså i vertens forsvar mot infeksjoner.

Bakteriedrap som følge av AMP-peptider ble påvist ved applikasjon av enten bakteriene eller deres peptider på hud fra menneske, gris eller mus forbehandlet med S. aureus. De AMP-produserende bakteriene var selv resistente mot peptidene, mens humane AMPpeptider, som skilles ut i lave konsentrasjoner fra intakt hud, forsterket drapet av S. aureus. Det var altså synergi mellom antimikrobielle peptider fra hhv. bakterier og mennesker.

Antimikrobielle peptider produseres av eukaryoter langt ned i dyrerekken, hos mennesker også av nøytrofile granulocytter og mastceller. Peptidene er kationiske, tiltrekkes av bakteriers cellemembraner (pga. negativ ladning på utsiden) og ødelegger dem eller hemmer deres transportfunksjoner.

- Denne studien gir et godt eksempel på hvordan ufarlige og vanlige bakterier beskytter mot patogene mikrober, sier Tone Tønjum, som er professor ved Avdeling for mikrobiologi, Universitetet i Oslo. Antimikrobielle peptider kan drepe både gramnegative og grampositive bakterier, så vel som virus, sopp og kreftceller. I motsetning til de fleste konvensjonelle antibiotika, ser det ut som om disse peptidene også kan styrke immunforsvaret ved å fungere som immunmodulatorer. Denne studien belyser samspillet mellom hudens mikrobiom og sykdomsbringende bakterier, noe som kan være viktig i kampen mot multiresistente bakterier.

\section{LITTERATUR:}

1. Nakatsuji T, Chen TH, Narala S et al. Antimicrobials from human skin commensal bacteria protect against Staphylococcus aureus and are deficient in atopic dermatitis. Sci Transl Med 2017; 9: eaah468o. [PubMed][CrossRef]

Publisert: 4. september 2017. Tidsskr Nor Legeforen. DOI: 10.4045/tidsskr.17.0406

(C) Tidsskrift for Den norske legeforening 2020. Lastet ned fra tidsskriftet.no 